\title{
Norsk som digitalt samhandlingsspråk i fire familier med innvandrerbakgrunn - identitet og investering
}

Kristin Vold Lexander, MultiLing, Universitetet i Oslo

\section{Sammendrag}

Denne artikkelen utvider kunnskapsgrunnlaget om norsk som andrespråk ved å belyse rollen språket spiller i digital samhandling i familien. Andrespråksinnlæreres oppfatning av egne språkbehov og -ønsker forandres i takt med bruken av digitalt mediert interaksjon (Darvin \& Norton, 2015; Douglas Fir Group, 2016). Migranter kan holde tettere kontakt med familie og venner i hjemlandet, samtidig som de kan bruke denne typen kommunikasjon til å bygge nettverk i landet de bor i, og til å utvikle sine språkkunnskaper, både i språkene de har med seg og språkene som brukes i den nye konteksten. Hvordan påvirker digitale språklige praksiser bruken av norsk i familier med innvandringsbakgrunn i Norge? Basert på intervjuog interaksjonsdata fra en studie av fire familier med senegalesisk bakgrunn i Norge, undersøker jeg følgende spørsmål: Hvordan benyttes digital interaksjon til å utvikle familiens norskkunnskaper? Hvilken rolle spiller familiemedlemmenes oppfatning av identitet for bruken av norsk i denne samhandlingen? Målet er å forstå hva digital interaksjon kan fortelle oss om norsk som andrespråk i familiekommunikasjon.

Nøkkelord: Digitalt mediert kommunikasjon, språkbruk i familien, uformell språklæring

\section{$1 \quad$ Innledning}

Andrespråksinnlæreres oppfatning av egne språkbehov og -ønsker forandres i takt med bruken av ulike verktøy for digitalt mediert interaksjon (Darvin \& Norton, 2015; Douglas Fir Group, 2016). Migranter kan holde tettere kontakt med familie og venner i hjemlandet, samtidig som de kan bygge nettverk i landet de bor i, og utvikle sine språkkunnskaper. Hvordan påvirker digitale språklige praksiser bruken av ulike språk i familier med innvandringsbakgrunn?

Forskning på språkbruk i familien gir oss kunnskap om hvordan dominerende diskurser om språk, skole og integrering samt politiske beslutninger påvirker språksosialiseringsprosessen (Fogle \& King, 2017). Studier av flerspråklige familier i Norge viser at norsk språk oppleves som «en redning» for å få jobb, men også som et fremmedelement hvis bruk skal unngås i enkelte situasjoner (Obojska \& Purkarthofer, 2018). Noen foreldre fors $\varnothing$ ker derfor å bruke bare ett språk, og ikke norsk, hjemme, for å utvikle barnas flerspråklighet (Purkarthofer \& Steien, 2019). Språkbruk i personlig digital kommunikasjon er imidlertid lite undersøkt i familiekonteksten (Lanza \& Lexander, 2019). Flere studier har sett på hvordan migranter lever familieliv på tvers av landegrensene gjennom digitale medier (Madianou, 2014), men 
også i familier som bor under samme tak, brukes digital kommunikasjon til å skape familieidentitet og samhold. Denne artikkelen vil belyse rollen språket spiller i slik digital samhandling.

Basert på intervju- og interaksjonsdata fra en studie av fire familier med senegalesisk bakgrunn i Norge, unders $\varnothing$ ker jeg hvordan digitalt mediert interaksjon benyttes til å utvikle familiens norskkunnskaper og hvilken rolle familiemedlemmenes konstruksjon av identitet spiller for bruk av norsk i slik kommunikasjon. Målet er å forstå hvordan digital bruk av norsk henger sammen med oppfatningen av språklæring, språkbehov og språkønsker, og hva dette kan fortelle oss om norsk som andrespråk i familiekommunikasjon. Jeg vil derfor særlig fokusere på språkbruk i lys av investering og identitet (Norton, 2013; Darvin \& Norton, 2015).

Etter en presentasjon av det teoretiske grunnlaget artikkelen bygger på i kapittel 2 og en kort beskrivelse av senegalesisk migrasjon til Norge i del 3, følger en skildring av metodene som ble brukt i datainnsamlingen i avsnitt 4 . I analysen i del 5 tar jeg først for meg bruken av norsk språk i lys av investeringsbegrepet, ved å studere holdninger til og bruk av personlige digitale medier for uformell språklæring. Jeg ser så på betydningen av identitet for bruken av norsk, blant annet ved å se på språkbruk i tid og rom (Busch, 2012).

\section{Digital kommunikasjon og flerspråklige familier}

Familiekonteksten er nyttig for å studere forholdet mellom språkbruk, ideologi og kapital på mikro- og makronivå. Forskningen som i de senere år blitt til feltet familiespråkpolitikk (King \& Lanza, 2019; Lomeu Gomes, 2018) søker nettopp å finne sammenhengen mellom familieekstern og familieintern språkpolitikk i flerspråklige familier. Foreldre med flerspråklige repertoar må velge hvordan de vil bruke språk med barna sine (Purkarthofer, 2017), samtidig som barna selv utøver språklig aktørskap i familiekonteksten (Said \& Zhu, 2018). Valgene som gjøres påvirkes av de ulike språkenes status og legitimitet i samfunnet og av språkideologier som igjen påvirker familiemedlemmenes roller og status i familien (King, 2013). Noen migranter oppfordrer barna til å lære og bruke det dominerende språket i landet de har flyttet til på bekostning av nedarvingsspråk, for at de skal lykkes med skolegang og arbeid (da Costa Cabral, 2018). En konsekvens av dette kan være at også nærhet mellom barn og foreldre uttrykkes på andrespråket, og et ambivalent syn på språkkompetansen i dette språket oppstår, særlig når det oppleves som at det gir svakere ferdigheter i førstespråket (Tannenbaum \& Yitzhaki, 2016). King (2013) påpeker at barn og foreldre definerer seg selv, sine roller i familien og familielivet med hensyn til språkkompetanse: familiemedlemmene får status etter hvor godt de snakker og skriver ulike språk. Språkpolitikk i familien innbefatter skriving og lesing (Curdt-Christiansen 2009), og som Stæhr (2015) påpeker, må skrift og tale undersøkes i sammenheng, særlig i en tid da teknologiens utvikling er på et punkt der skriftlig interaksjon ernæres av sosiale medier. 
Skriftlig digital interaksjon er blitt en viktig del av familiekommunikasjonen, sammen med de muntlige samtalene rundt middagsbordet, foran TV, i forhandlinger om utetider. Her koordineres hverdagen, her gis det beskjeder, samtidig som familieidentiteten forhandles og reforhandles. Hvilken rolle spiller denne digitale kommunikasjonen for språklige praksiser og språkkompetanse?

Språklæring foregår digitalt, på og rundt skjerm, både i pedagogisk bruk av digitale media (Gee \& Hayes, 2011; Johanson \& Karlsen, 2018) og i uformelle aktiviteter, som kommentarer til YouTube-videoer (Benson, 2015). Dette skjer også i familiekonteksten. I flerspråklig samtale rundt dataskjermen blir ulike språklige ressurser benyttet, og deltakerne fra ulike generasjoner kan lære av hverandre uten at lærer- og elevrollen er klart definert (Kenner mfl., 2008, Parven, 2016). Foreldre i migrantfamilier legger til rette for at barna skal kunne kommunisere digitalt på språk fra hjemlandet (Szecsi \& Szilagyi, 2012), og søsken hjelper hverandre med både nytt språk og ny teknologi, for eksempel i bruk av kalender på mobiltelefonen (Kheirkah \& Cekaite, 2017). Friheten til å stave ord på ulike måter, uavhengig av formelle rettskrivningsregler, og til å blande ulike språk i én og samme tekst, gjør at terskelen for å skrive, også flerspråklig, framstår som lavere (Lexander, 2011). Dette kan gjøre det lettere å ta i bruk andrespråk i kommunikasjon.

I tråd med den sosiale dreininga på andrespråksfeltet (se oversikt i Opsahl \& Aarsæther, 2015), har identitet i større grad blitt tatt i bruk som et analytisk begrep for å beskrive språkutviklingsprosesser (se Jølbo, 2014; Wedin, 2017). Investeringsmodellen (model of investment, Darvin \& Norton, 2015: 42) er utviklet for å forstå språklæring fra språkinnlærers perspektiv og å sette dette i sammenheng med maktstrukturer i samfunnet for $\varnothing v$ vrig. I stedet for å snakke om motivasjon til å lære, brukes begrepet investering om individets opplevelse av engasjement og dedikasjon knyttet til å lære et språk. Dette engasjementet må forstås i lys av de tre begrepene identitet, kapital og ideologi.

Norton (2013: 4) definerer identitet som måten en person forstår sitt forhold til verden på, hvordan dette forholdet er plassert i forhold til tid og sted og hvordan personen ser sine muligheter i framtida'. Med identitet menes altså ikke en statisk størrelse, som kjønn, etnisitet og sosial status; identitet er dynamisk og forhandles fortløpende fram i (språklig) samhandling (Androutsopoulos \& Georgakopoulou, 2003: 1). Forhandlingen skjer på mikronivå i interaksjon mellom mennesker, men er knyttet til sosioøkonomiske, -historiske og -politiske prosesser på makronivå (Pavlenko \& Blackledge, 2004: 3). Språkinnlæreres investering i å tilegne seg nye språkkunnskaper er også knyttet til deres forestilte identiteter (imagined identity): hva slags framtid de ser for seg, og hvordan de ser seg selv med utgangspunkt i tidligere erfaringer. , Engasjementet henger også sammen med deres forståelse av de symbolske og materielle ressursene disse språkkunnskapene er knyttet til (Darvin \& Norton, 2015), i form av kulturell kapital og symbolsk makt (Bourdieu, 1982). Hvilke muligheter for sosial mobilitet og hvilken makt til å oppnå det livet en ønsker knyttes til en bestemt type språklige ressurser? Svaret på dette spørsmålet avhenger av rådende 
ideologier i samfunnet, ikke bare språkideologier, men også dominerende syn på sosial klasse, kjønn og etnisitet. Investering i et språk blir dermed til i et komplekst samspill mellom individets egne tanker og ønsker om forandring og tilpasning, og storsamfunnets regler og dominerende diskurser om innvandring og integrering.

I diskusjoner om innvandring i Norge settes det gjerne likhetstegn mellom norskkunnskaper og integrering. Norskkunnskaper innebærer norsk skriftspråk, der det er to standarder, bokmål og nynorsk. Det omfatter også norsk talespråk, der det ikke er noen formell standard, men standard østnorsk er gjerne talemålet som brukes på norskkurs (Røyneland \& Uri, 2020). Dialektbruken er ellers utstrakt i Norge, i formelle som uformelle situasjoner. Røyneland og Uris (2020) studie av språkholdninger viser at dialektbruk av personer med innvandrerbakgrunn påvirker hvordan de blir oppfattet. De som snakker en annen dialekt en den som dominerer i Oslo, oppfattes som mer «norske» enn andre. En annen type identitet kan signaliseres ved bruk av den multietnolektiske språkstilen som har utviklet seg i urbane strøk, og særlig i enkelte deler av Oslo. Der brukes blant annet en rekke ord og uttrykk fra ulike innvandrerspråk til å uttrykke en viss type ungdomsidentitet (Hårstad \& Opsahl, 2013). Mange bruker trekk fra muntlig kommunikasjon på sosiale medier og når de skriver tekstmeldinger. Dette gjelder særlig unge (Rotevatn, 2014), men også voksne (se for eksempel Røyneland, 2018), og avsender varierer språket med den de skriver til. Særegne stavenormer for å understreke lokal egenart oppstår i disse skriftpraksisene, og ukonvensjonelle forkortelser er vanlig (Skog, 2009; Strand, 2019). Uformell digital kommunikasjon er dermed et rom der en kan eksperimentere med språk, benytte kunnskaper om både skriftlig og muntlig språk, og uttrykke identitet gjennom særegne måter å skrive på. Hvordan bruker innvandrerfamilier norsk i dette rommet?

\section{$3 \quad$ Senegalesiske migranter i Norge}

Det er ikke mange senegalesere i Norge, og innvandringen fra Senegal er relativt ny. Ifølge Statistisk Sentralbyrå (mars 2020) er det 314 senegalesiske innvandrere i Norge og 103 barn født i Norge av senegalesiske foreldre. Kun 13 personer er såkalt tredje generasjon, altså $f \varnothing d t$ av foreldre som er $f \varnothing d t$ i Norge med senegalesiskf $\varnothing d t e$ besteforeldre. Det lave antallet har betydning for muligheten til å bruke språk og å delta i aktiviteter knyttet til senegalesisk kultur. Utvalget i denne studien består av både innvandrere, barn født i Norge med senegalesiskf $\varnothing \mathrm{dte}$ foreldre og barn $f \varnothing \mathrm{dt}$ av én senegalesisk forelder og én norsk forelder.

Wolof er det mest talte språket i Senegal (80-90\% av befolkningen), sammen med minoritetsspråk som fulfulde, joola og seereer. Siden fransk er offisielt språk og eneste undervisningsspråk i Senegal, og de andre senegalesiske språkene kun blir brukt til alfabetiseringskurs i uformell sektor, lærer de færreste å skrive disse språkene. Men, på samme måte som norske unge tar i bruk dialekt når de skriver digitale meldinger, bruker senegalesere, og særlig unge, språk de ellers kun bruker muntlig når de skriver 
tekstmeldinger, der de tar i bruk hele repertoaret sitt av språklige ressurser (Lexander, 2018). I tillegg har mange en viss arabiskkompetanse etter å ha gått på koranskole, og noen har studert engelsk og spansk på skolen. Andre har oppholdt seg i ulike europeiske land og lært seg språk som italiensk. Senegaleserne i studien har dermed et rikt språklig repertoar en av deltakerne kunne seks språk da hun kom til Norge som tenåring. Alle familiene i studien snakker wolof og fransk, og tre familier snakker et eller flere senegalesiske språk i tillegg (fulfulde, joola, se tabell 1).

Den flerspråklige bakgrunnen påvirker synet på å lære seg norsk og synet på forholdet mellom språk og identitet: det å lære nye språk er en del av livet for mange senegalesere (Weidl, 2019), slik det er for andre migranter med flerspråklig bakgrunn (Golden \& Steien, 2018). Synet på å lære seg norsk henger også sammen med politiske føringer. I Norge behandles norsk språkkompetanse som den ene avgjørende faktoren for vellykket integrering (Kulbrandstad, 2017). Som analysen viser, deler deltakerne delvis dette synet.

\section{Metode}

Prosjektet denne artikkelen bygger på utforsker digitale språkpraksiser $\mathrm{i}$ familiekommunikasjon innad i husholdet og på tvers av landegrensene. For å kunne belyse sammenhengen mellom syn på språk og kommunikasjon og språklige praksiser i digital samhandling, ble ulike typer data samlet inn gjennom en kvalitativ unders $\varnothing$ kelse. Fire familier (se tabell 1), som alle har vært i Norge i 10-15 år, ble fulgt over to år (2017-2019). Datainnsamlingen besto av delvis strukturerte intervju, der fokuset var på ett og ett medlem av gangen, mens de andre familiemedlemmene kommenterte underveis. I tillegg deltok alle fire familier $\mathrm{i}$ to felles fokusgrupper. Data fra familiemedlemmenes digitale kommunikasjon ble også samlet inn. Familiene ble rekruttert gjennom eget nettverk og snøballprinsippet, der det ble lagt vekt på å finne familier med ulik etnisk og geografisk bakgrunn, som hadde vært relativt lenge i Norge, og som hadde barn som var store nok til å bruke digitale medier. Som tabell 1 viser, er det ulikheter mellom familiene når det gjelder antall språk de bruker, noen familier har flere språk med seg fra Senegal, andre har wolof og fransk. 
Tabell 1. Oversikt medlemmer i deltakerfamiliene og språk de bruker

\begin{tabular}{|l|l|}
\hline Familienavn og - medlemmer & Språk brukt i familien (i følge familiene selv) \\
\hline $\begin{array}{l}\text { Familien Diagne: Mor, far, } 3 \\
\text { barn }\end{array}$ & Wolof, fransk, norsk (noe arabisk) \\
\hline Familien Coly: Mor, 4 barn & $\begin{array}{l}\text { Wolof, fransk, norsk, engelsk, spansk, arabisk, joola } \\
\text { (kun mor) }\end{array}$ \\
\hline $\begin{array}{l}\text { Familien Bâ: Mor (født i Norge), } \\
\text { far, } 2 \text { barn }\end{array}$ & $\begin{array}{l}\text { Wolof, fulfulde, joola, norsk, fransk, engelsk, italiensk, } \\
\text { spansk, arabisk, to asiatiske språk }\end{array}$ \\
\hline Familien Sagna: Far, 1 barn & $\begin{array}{l}\text { Wolof, joola, fransk, engelsk, seereer, norsk og japansk } \\
\text { (kun datter) }\end{array}$ \\
\hline
\end{tabular}

På første møte med familiene ble visuelle hjelpemidler (språkportrett og tegning av mediekart) brukt for å samle inn intervjudata om språklige repertoar og de ulike familiemedlemmenes digitale kommunikasjon med hverandre og med slektninger utenfor Norge. Språkportrett er et verkt øy utviklet for å undersøke hvordan vi oppfatter våre språklige repertoar som plassert i tid og rom (Busch, 2012). Den som intervjues, får utdelt en silhuett av en menneskekropp og skal så tegne og fargelegge språk som betyr noe, og har betydd noe, i livet til vedkommende. Når tegningen er ferdig, forteller den intervjuede hva han/hun har tegnet og hvorfor, hvordan levd liv og oppfatningen av egne språklige ressurser, praksiser og holdninger henger sammen (Busch, 2012: 518-519). Møtene med familiene startet med språkportrettegning og intervju, før vi i samarbeid tegnet et mediekart, en oversikt over hvem de kommuniserer med digitalt, samt de ulike mediene og språkene de benytter seg av. Deltakerne valgte så ut digitale interaksjonsdata, fra apper som WhatsApp, Messenger og SMS, som ble samlet inn, enten ved nedlasting og videresending eller skjermdumper. Noen ganger ble de spurt om de kunne dele samtaler med spesifikke samtalepartnere som kom fram som interessante i intervjuene, andre ganger kom de selv med forslag til data. Fokuset i studien var på flerspråklighet. Jeg snakker og skriver wolof og framstår nok gjerne som mer interessert i bruk av dette språket enn i norsk, siden et viktig spørsmål i undersøkelsen var om digital kommunikasjon førte til mer bruk av wolof i familien. Det er derfor ikke grunnlag for å regne med at deltakerne prioriterte å dele meldinger på norsk, kanskje heller tvert imot. De lange utdragene fra husholdets digitale kommunikasjon viser et klart mønster av norsk språklig dominans (se figur 2). Samtidig må det nevnes at noen deltakere var opptatt av å fremheve bruken av norsk i intervjuer (se 5.1).

Før deltakelse fikk familiene forelagt et skriftlig skjema for informert samtykke, med én tekst tilpasset voksne og én som skulle forklare barna hva undersøkelsen gikk ut på. Alle data ble anonymisert, og personlige opplysninger som nøyaktig alder og bosted er utelatt for å unngå identifisering. Deltakerne tok selv kontakt med sine samtalepartnere for å spørre om tillatelse til å bruke kommunikasjonen deres i prosjektet. Etter møtet ble de innsamlede dataene kodet for språkbruk, type kommunikasjonsmiddel og modalitet (skriftlig/muntlig) for hvert familiemedlems samtalepartnerne. Kodene ble så brukt til å lage en graf som gir en 
oversikt over de enkelte familiemedlemmenes kommunikasjon, et "mediagram» (Lexander \& Androutsopoulos, 2019). Dette mediagrammet ble diskutert på neste møte med deltakerne, for å rette opp eventuelle misforståelser, fylle inn manglende data, samt ta inn endringer i kommunikasjonen og eventuell bruk av nye digitale verktøy. Slik får en oversikt over den digitale kommunikasjonen som helhetlig praksis, i stedet for å fokusere på bare ett kommunikasjonsmiddel. Jeg spurte også etter nye interaksjonsdata, som deltakerne kommenterte (jfr. play back sessions, Rampton, 1995), og jeg laget så en oppdatert versjon av mediagrammet på bakgrunn av dette. Oppfølgingsintervjuer ble gjentatt i flere runder (35 møter per familie), før mediagrammet ble brukt sammen med dataene til analyse av kommunikasjonen (se figur 1 ).

[Figur 1. Datainnsamling og -analyse steg for steg]

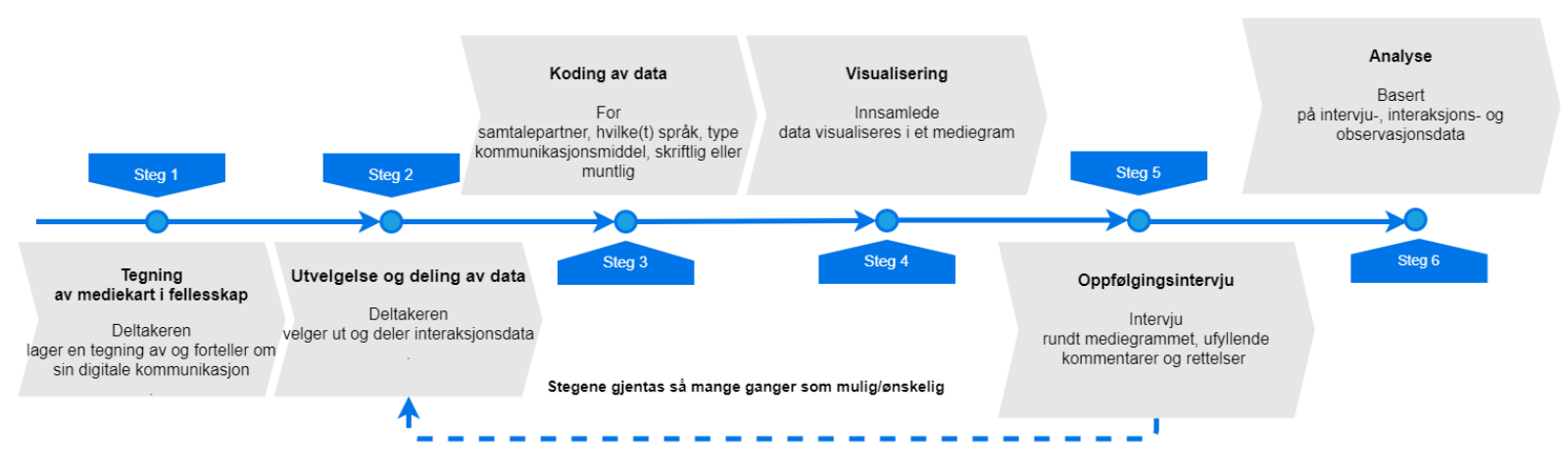

Mediagrammene viser flerspråklig kommunikasjon innad i familien, men er ikke laget for å skille kvantitativt i bruken mellom språkene. Norsk-dominansen blir derimot klar i den visuelle framstillingen av datamaterialet i figur 2. I alle familiene viser det seg at norsk er det mest brukte språket i digital kommunikasjon innad i husholdet, basert på 115 innsamlede skjermdumper. I tillegg brukes fransk, arabisk og engelsk - men ikke wolof.

[Figur 2 Språkbruk i hushold-intern kommunikasjon i fire norsk-senegalesiske familier] 


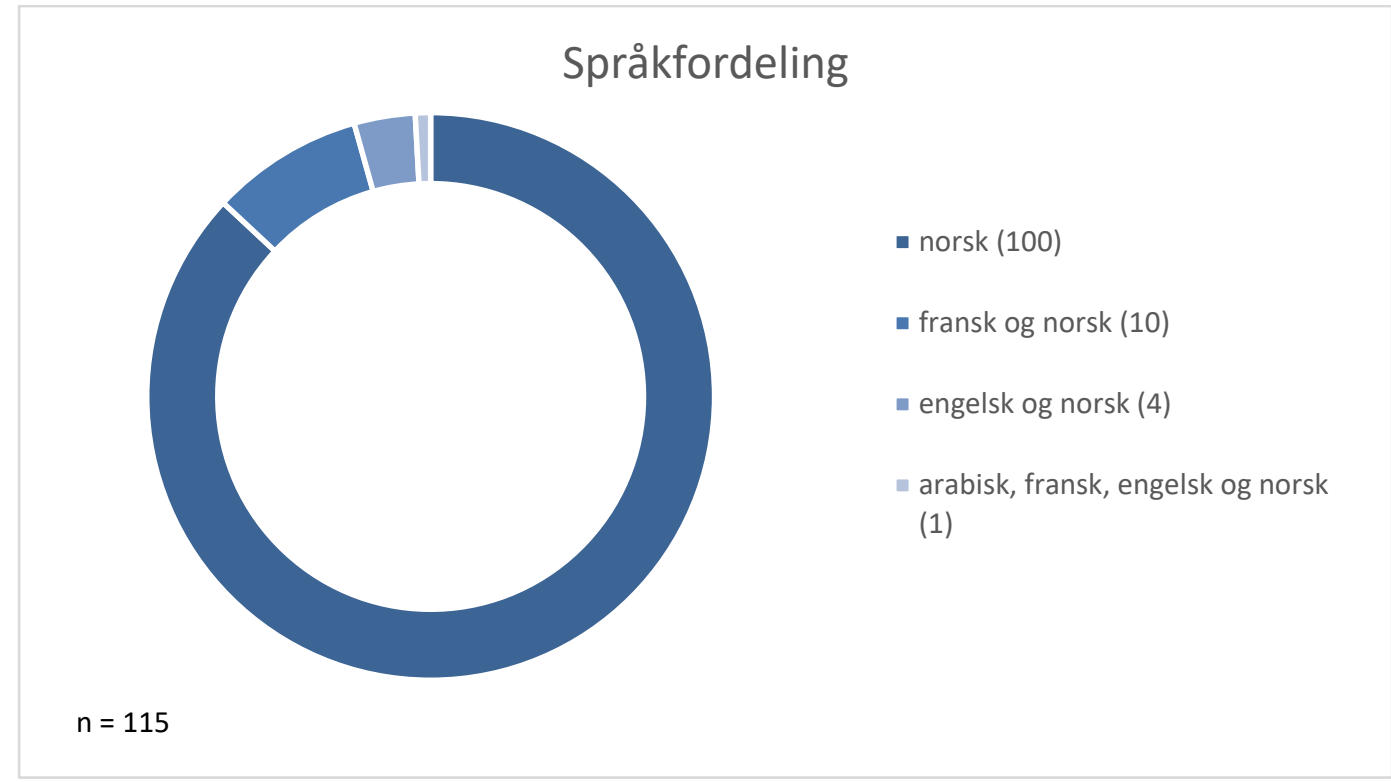

Metoden fulgt i denne studien gir på den ene siden grunnlag for kunnskap om familienes språklige repertoar, deres repertoar av digitale ressurser og samtalepartnere, samt deres refleksjoner rundt egen bruk av digitale medier. Dette er nødvendig for å kunne si noe om investering og språkbruk. Vi får videre innsikt i hvordan samtalene forløper og deltakernes tolkning av ulike samtaler. Slik kan vi studere hvordan digital bruk av norsk inngår i den kontinuerlige prosessen av å skape, gjenskape og omskape identitet i familien.

\section{$5 \quad$ Norsk som digitalt samhandlingsspråk i familien}

I analysen av kommunikasjon innad i husholdet i Norge vil jeg først se på digital kommunikasjon som en potensiell læringsarena, der familien kan investere i språkkompetanse. I hvilken grad benyttes dette rommet strategisk til å utvikle norskkunnskaper? I andre del knytter jeg analysen til forskning på familiespråkpolitikk, og ser på hvordan norsk brukes til å forhandle familiebånd og -identitet digitalt. Hvorfor bruker familiene norsk språk når det er flere alternativer tilgjengelig, også språk de i utgangspunktet behersker bedre?

\subsection{Investering - digital kommunikasjon som læringsarena for norsk språk}

En forutsetning for å videreutvikle innlærte norskkunnskaper gjennom digital kommunikasjon i familien, er at norsk faktisk brukes. Som figuren i forrige avsnitt viste, er denne forutsetningen oppfylt. Norsk er det dominerende språket i personlig digitalt mediert kommunikasjon innad $\mathrm{i}$ husholdet $\mathrm{i}$ alle de fire familiene. Figur 3 gir en oversikt over språkbruk innad i familien Diagne, inkludert en nær senegalesisk venn av familien som bor $\mathrm{i}$ nabolaget, basert på 71 skjermdumper.

[Figur 3 Språkbruk i hushold-intern kommunikasjon i familien Diagne] 


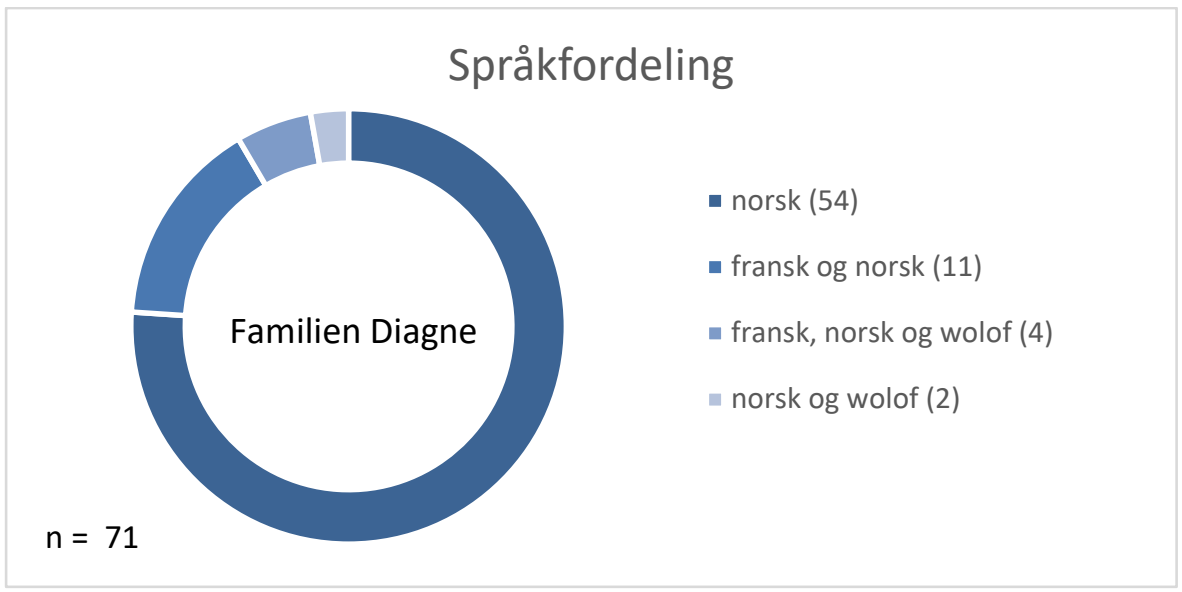

Figuren viser at norsk dominerer, og at språket noen ganger brukes sammen med fransk og wolof. Hvis vi går inn på grunnlaget for figuren, ser vi at der far og sønn, far og datter, mor og sønn og mor og datter kommuniserer, brukes bare norsk. I meldinger sendt mellom mor og far er norsk brukt alene eller sammen med fransk. En ville kanskje tro at far Diagne brukte muligheten til å snakke og skrive wolof med de få senegalesiske vennene han har i Norge, men innsamlede skriftlige meldinger viser at norsk brukes i stor grad, mens wolof brukes av og til, for kallenavn og hilsener. Disse meldingene med familiens nære venn skiller seg imidlertid fra den hushold-interne kommunikasjonen ved at det brukes noe wolof.

Sett i forhold til forskning på flerspråklige familier, er det kanskje mer overraskende at ekteparet Diagne, som begge har wolof som første talte språk og fransk som første skriftspråk, skriver til hverandre på norsk, enn at de gjør det med barna, som jo har norsk som første skriftspråk. I intervjuene viser det seg at dette blant annet henger sammen med synet på digital kommunikasjon som en god språklæringsarena, og vi vil nå se nærmere på først familien Diagnes kommunikasjon, så interaksjon i familiene Sagna og Bâ.

Familien Diagne består av mor, far og tre barn. Far kom til Norge seks år før mor, og han snakket godt norsk da hun kom. Ti år senere er han fortsatt opptatt av at hun skal forbedre norskkunnskapene sine, og i intervjuet i utdrag 1 har han akkurat fortalt at han kun skriver norsk til kona når de tekster hverandre.

Intervjudata, utdrag 1

Kristin hvorfor det?

Far Diagne nei, bare for å få henne til å lære seg bedre norsk, til å bli litt bedre kjent med nye ord, for at... jeg bruker ikke ofte fransk, eller fransk når jeg snakker eller ringer eller tekster til henne da, det er bare for å få ho til å snakke norsk

Fars utsagn kan ses i sammenheng med familien Diagne sin strategi for best mulig integrering i det norske samfunnet. De har blant annet bevisst bosatt seg i et område med få innvandrere. Barna foretrekker oftest norsk. De bruker av og til wolof når de snakker til foreldrene, men i tekstmeldinger er det kun norsk. Parets to eldste barn har mobiltelefoner, og den eldste sønnen bruker norsk dialekt når han skriver til foreldrene, mens søsterens og 
foreldrenes meldinger er nærmere standard bokmål. Tekstmeldinger samlet inn fra foreldreparets mobiltelefoner viser som nevnt at det stort sett går i norsk også dem imellom, og de viser også at mannen retter konas skrivefeil. I eksempel 1 nedenfor korrigerer han hennes «kjapp av», som kan se ut som en skrivefeil, men som også kan komme av en misforståelse i uttale, til «slapp av».

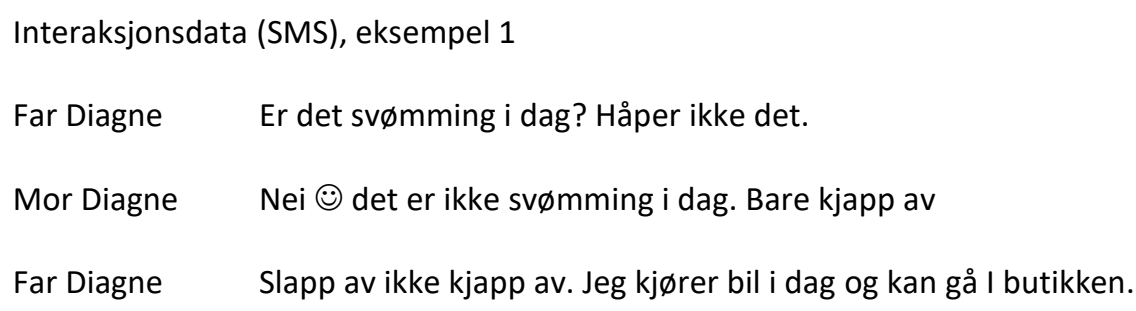

Dataene inneholder i tillegg et eksempel på at faren retter datterens bruk av og/å i en tekstmelding. Disse korreksjonene kan være med på å underbygge hans autoritet, både som ektefelle og far, gjennom at han posisjonerer seg som røkter av «korrekt» språkbruk i familien. Mens mor har kortere botid i Norge enn far, er datteren født i Norge og behersker norsk med førstespråkkompetanse. Når far retter på datteren, viser han seg som et godt språklig forbilde i norsk, og at han, som datteren, er norskspråklig kompetent, selv om det ikke er hans første- eller andrespråk. I begge tilfeller påpeker han indirekte viktigheten av «korrekt» norsk som norm i familien, en type skriftlig språkpolitikk. Fokuset på korrekt språkbruk omfatter allikevel ikke sønnens dialektbruk i tekstmeldingene. Denne kommenteres ikke, hverken i interaksjonsdata eller intervju, og det dukker av og til opp dialekttrekk i farens meldinger også. Dette kan forstås i lys av Røyneland og Uris (2020) funn om sammenhengen mellom dialektbruk og det å bli oppfattet som «norsk».

Den yngste sønnen deler familiens muntlige språklige repertoar inn i «ordentlig språk», norsk, som de bruker i barnehagen, og "Senegal-språk», som er wolof. "Snakk ordentlig, mamma!» sier han til moren, ifølge moren selv. Mor er altså under stadig press fra flere familiemedlemmer for å bruke norsk språk og å videreutvikle det, mens hun på sin side $\emptyset n s k e r$ å bruke wolof med barna. Hun forteller at hun er «redd for at de glemmer helt, så hjemme vil jeg bare snakke wolof til dem, norsk bruker jeg ute med kollegaer og sånt. Og på jobben.». Men selv om hun prøver å snakke wolof til barna hjemme, bruker hun altså norsk når hun skriver meldinger til dem. Dette henger sannsynligvis sammen med språkenes rolle som skriftspråk i Norge og i Senegal. Både hun og barna har lært å skrive norsk, men ingen av dem har lært å skrive wolof. Siden hun har senegalesisk skolegang, leser og skriver hun fransk, og det hender at foreldreparet bruker franske ord i SMS-utvekslingen seg imellom. I eksemplet nedenfor ser vi tekstmeldinger fra tre ulike dager der ekteparet Diagne avtaler hvem som skal hente den yngste sønnen i barnehagen. Avtalen gjøres på norsk, mens fransk brukes for å si cheri, ma chere og chou,'(min) kjære'.

Interaksjonsdata (SMS), eksempel 2

Mor Diagne Hei! Kan du hente [yngste sønn] pappa cheri 


$$
\begin{array}{ll}
\text { Far Diagne } & \text { Ok ma chere kona } \\
\text { Far Diagne } & \text { Henter [yngste } s \emptyset \mathrm{nn} \text { ] i dag } \\
\text { Mor Diagne } & \text { Ok } \odot \text { pappa cheri } \\
\text { Far Diagne } & \text { Chou kan hente [yngste } s \varnothing \mathrm{nn} \text { ] }
\end{array}
$$

I denne meldingsutvekslingen brukes fransk til å uttrykke intimitet, samtidig som det praktiske avtales på norsk. Mor Diagne bruker også kallenavnet «pappa», som har en mye videre betydning og bruk i Senegal, hvor ordet er lånt fra fransk, enn i Norge. Dette eksemplet skiller seg altså fra det første eksemplet i denne artikkelen, der far retter på mor. Her er det mor som leder an med franske uttrykk som en tilknytningsmanøver i ellers norskspråklige meldinger, og mannen følger hennes språkvalg, i en SMS-utveksling som skaper nærhet. Da dette eksemplet kom opp i intervjuet, hadde jeg spurt mor og far Diagne om hvilke språk de brukte i tekstmeldinger. Mor sa at det var norsk og fransk, og far sa mest norsk. Da jeg påpekte at chéri var skrevet på fransk, lo mor, mens far gjentok at det stort sett var norsk, men at «det er litt fransk, da». Inntrykket av fars prioritering av norsk forsterkes, samtidig som vi ser at han følger mors ønske om å bruke franske ord for styrke båndet dem imellom.

Eksemplene fra familien Diagne viser hvordan en rekke handlinger i familien utføres ved hjelp av tekstmeldinger. De organiserer innkjøp og henting, fritidsaktiviteter og innetider, hovedsakelig gjennom bruk av norsk. I familien Sagna finner vi lignende eksempler, der husholdningen bestående av far og datter. De koordinerer middagslaging og holder rede på hverandres bevegelser gjennom tekstmeldinger på Messenger. Datteren har kort botid i Norge, men allerede ved prosjektets oppstart var de to i full gang med å skrive tekstmeldinger på norsk til hverandre, hun hadde allerede lært godt sitt syvende språk. Selv om deres bruk av norsk har trekk av andrespråkbruk, er dette det dominerende språket. Begge har skriftspråkkompetanse i fransk, og både far og datteren selv ønsker at datteren skal styrke franskkompetansen. Gode norskkunnskaper og ferdigheter i senegalesiske språk er ingen motsetning, begge deler er mulig og ønskelig. Allikevel trumfer norsk fransk i

\begin{tabular}{|c|c|}
\hline Far Sagna & Du tar laksen ut legge den FRISEN \\
\hline Datter Sagna & hæ \\
\hline Datter Sagna & ta den ut eller lege den i frisen forstår ikke hva du sier \\
\hline Far Sagna & Frysen \\
\hline Datter Sagna & \\
\hline
\end{tabular}
meldingene de sender til hverandre.

I det første utdraget fra kommunikasjonen deres er datteren hjemme og skal lage mat til seg selv og halvsøsteren, på farens instrukser. 


$\begin{array}{ll}\text { Far Sagna } & \text { Kan finne min lommeboka } \\ \text { Datter Sagna } & \text { vi spisser fortsatt og jeg har lagd veldig gode pannekaker } \\ \text { Far Sagna } & \text { Så bra }: ; \text { flink du er } \\ \text { Datter Sagna } & \text { takk }\end{array}$

Farens instruksjoner er litt utydelige på grunn av preposisjonsbruken. Datteren sender derfor en tekstmelding med den muntlige interjeksjonen «hæ» for å vise at hun ikke forstår. Hun følger opp med en ny melding der hun presiserer hva hun ikke forstår, skal hun ta laksen ut av fryseren eller legge den i fryseren? Faren forstår det som at hun lurer på hva han mener med «FRISEN» og retter til «Frysen». I mellomtiden har datteren sannsynligvis funnet laksen og forstått oppdraget, og hun melder «ok» for å gi beskjed om dette. Faren sender en melding om lommeboka, mens datteren svarer med statusrapport om middagen. Faren roser henne med smilefjes og datteren takker. De kommuniserer altså på norsk, selv om forståelse av og til må forhandles fram. Slik jobber de med sin kommunikative kompetanse i norsk sammen, på en måte som kan styrke båndene deres til hverandre. Et annet eksempel fra deres hverdagskommunikasjon sier noe om rollen det norske språket spiller for dem:

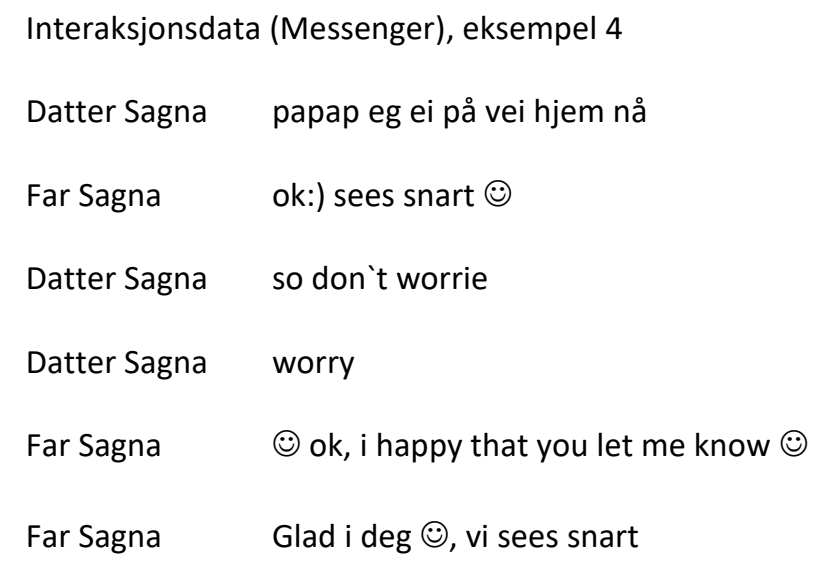

Datteren er ikke hjemme, men opplyser at hun er på vei. Igjen får hun positive reaksjoner fra faren, i form av smilefjes. Datteren går så til engelsk for å si at han dermed ikke trenger uroe seg. Hun korrigerer stavemåten for "worry», som for å understreke at hun vet hvordan det skrives korrekt, selv om skrivemåten «worrie» ikke hindrer forståelsen. Dette ligner på farens korrigering av «FRISEN» til «Frysen» i eksemplet ovenfor. Vi ser at faren følger datteren i bruken av engelsk når han roser henne for gesten, før han går tilbake til norsk for å si at han er glad i henne. Han velger altså norsk til dette budskapet, samtidig som han aksepterer og følger datterens bruk av engelsk, slik far Diagne følger mor Diagne sin bruk av fransk. Men mens ekteparet Diagne bruker fransk til kjærlige ord, bruker far Sagna norsk i sin kjærlighetserklæring til datteren. Dette kan ses på som en markert vending tilbake til norsk, som hovedspråk for deres samhandling, eller som at far Sagna synes norsk er det mest nærliggende språket å si «Glad i deg» på. Ofte er det førstespråket som brukes til dette i en flerspråklig familie, men når foreldrene fokuserer på andrespråkslæring, kan språkvalget 
skifte (Tannenbaum \& Yitzhaki, 2016). I både familien Diagne og Sagna går små lommer av $\emptyset$ mhet og språksosialisering hånd $\mathrm{i}$ hånd $\mathrm{i}$ en ellers travel hverdag.

I familien Bâ, bestående av mor født i Norge, far født i Senegal og to barn født i Norge, er det språkinnlæreren selv som er pådriver for bruk av norsk i tekstmeldingene. Far Bâ synes tekstmeldinger er nyttig for å utvikle norskkunnskapene sine og sier at paret derfor har gått over til å skrive på norsk i stedet for fransk og wolof når de tekster hverandre. Men han påpeker at kona ofte svarer på fransk fordi hun er redd for at han ikke skal forstå.

På ulike måter benyttes altså digital samhandling i familien som arena for utvikling av norskkunnskaper. Norsk er innlæringsspråk, og bruken av dette språket påvirkes av ønsket om å underbygge egen og andres språklæring. Men det er også språk for hverdagsrutiner og i noen tilfeller for kjærlighetserklæringer. Ulike aktører har ulike strategier og mål. Far Diagne korrigerer andre, far og datter Sagna korrigerer seg selv, mens far Bâ velger norsk for sin egen del, nettopp fordi han behersker det i mindre grad enn andre språk i familiens repertoar. Samtidig er språklæringen som skjer i dette rommet samhandling, avhengig av at partene samarbeider. Og gjennom samarbeid skapes samhold og familieidentitet.

\subsection{Identitet, norsk språk og flerspråklighet}

Hvordan påvirkes bruken av norsk språk i digital interaksjon av familiemedlemmenes oppfatning av samfunnet rundt seg og framtidige muligheter (Darvin \& Norton, 2015)? Hvilken plass har norsk i de ulike medlemmenes levde liv? Som nevnt i del 4 har alle deltakerne i undersøkelsen tegnet et språkportrett (Busch, 2012), nettopp for å se på hvordan deltakerne tenker om språk i livene sine. Jeg vil nå presentere språkportrettet til den eldste sønnen i Diagne-familien for å illustrere hvordan forholdet til ulike språk forandrer seg gjennom livet. Den unge mannen kom til Norge som 6-åring, etter at han fram til da hadde bodd sammen med storfamilien i Senegal.

[IIlustrasjon 1. Språkportrett av den eldste sønnen i familien Diagne] 


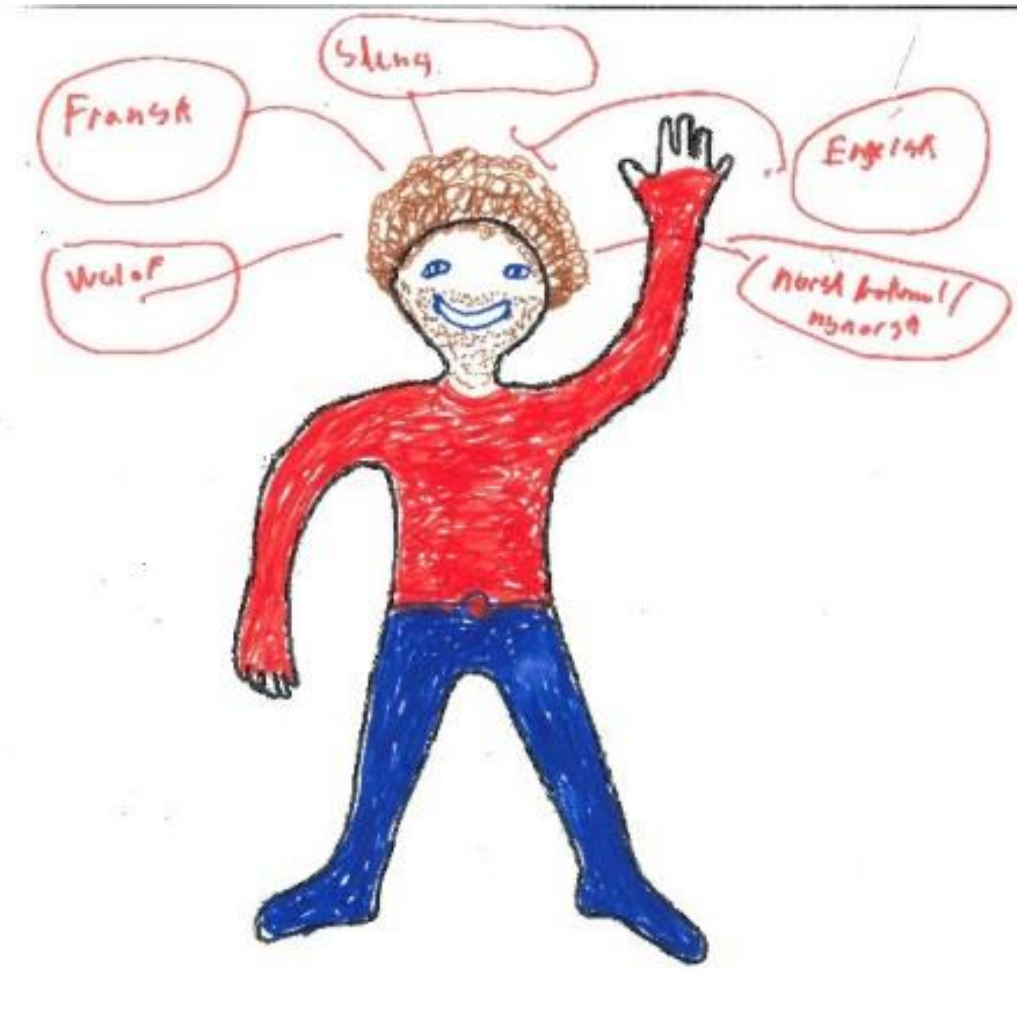

På tegningen ser vi en smilende person med krøllete hår og skjegg som har fem bobler rundt hodet. I hver boble står et språk eller en varietet: «wolof», "fransk», «sleng» (slang), «engelsk», «norsk bokmål/nynorsk». I intervjuet sier eldste sønn Diagne at han har laget en tegning av en mann «som er litt forvirra» fordi han «liksom skal kunne så mye språk, så han kan blande litt». Vi ser at han deler morens oppfatning av at han ikke må glemme wolof, og han uttrykker at han ønsker å lære mer av alle språkene han bruker.

Intervjudata, utdrag 2

Eldste $\varsigma \varnothing n n$ Diagne

det er alle språkene han kan litt av og han kan litt av alle språkene og han skal prøve å lære seg litt mer norsk og wolof og huske wolof. Det er liksom litt slik jeg har det nå, fordi at jeg må jo prøve å huske litt på wolof og så må jeg fortsette med å lære norsk og, jeg kan jo norsk, men det er jo fortsatt ting som jeg fortsatt må lære meg, engelsk også må jeg lære meg og fransk og litt slangspråk og litt sånn.

Ut fra tegningen ser norsk ut til å henge sammen med skolegang og skriftspråk, siden han nevner bokmål og nynorsk og plasserer disse i samme boble. Slang står i en boble for seg og representerer en språklig praksis som han ganske nylig har tatt i hyppig bruk, særlig muntlig. Etter å ha gått på en skole i nabolaget med få minoritetsspråklige elever, har han begynt på en videregående skole der det er flere med innvandringsbakgrunn, og der går det mye i slang: «Litt arabisk og kebab-norsk og sånn» «Jeg må liksom prøve å tilpasse meg», sier han. Nynorsk og bokmål er viktig for han fordi han ønsker å ta høyere utdanning, mens den multietnolektiske språkstilen er viktig for tilhørighet i ungdomsgruppa. Med familien både snakker og skriver han den regionale dialekten, i tillegg til wolof, som han også bruker med slektninger i hjemlandet. Fransk er et språk han lærer på skolen, hører når han ser sport på 
TV med faren og bruker sammen med wolof når han kommuniserer med folk i Senegal.

Engelsk har lignende betydning. Han lærer det på skolen, og bruker det med særlig én fetter. De ulike boblene representerer ulike fellesskap i livet hans, der ulike former for språkbruk skaper tilhørighet. Vi finner en lignende situasjon i familien Coly.

I motsetning til Diagne-familien bor familien Coly i et område med stor andel flerspråklige familier, og der mange bruker multietnolektisk stil når de snakker norsk. I intervjuutdrag 3 ser vi at moren skiller mellom standard og slang når hun kommenterer barnas norskbruk i tekstmeldinger.

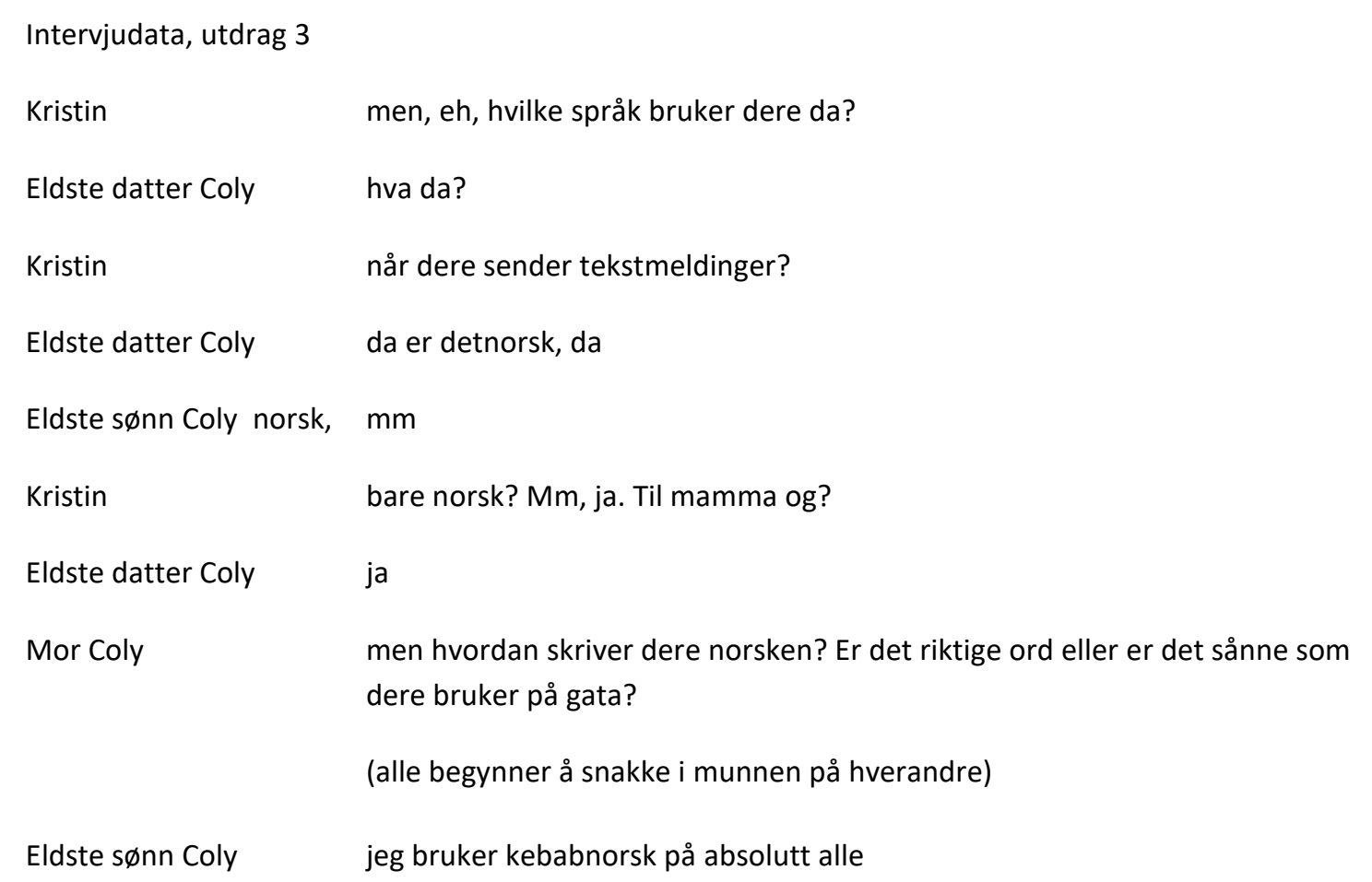

Familiemedlemmene er skjønt enige om at de kun skriver tekstmeldinger til hverandre på norsk. Moren påpeker imidlertid at det er ulike måter å skrive norsk på, og oppfordrer dem til å presisere om de skriver «riktige» ord, eller «sånne som dere bruker på gata». Underforstått, slang, slik sønnen sier at han bruker, er feil. Denne normativiteten styrkes videre i intervjuet, når moren forteller at hun ikke liker slang og ukonvensjonelle stavemåter, slik hennes bror i Senegal bruker i meldinger på fransk. Moren ønsker altså at de skal bruke en mer prestisjefylt varietet av skriftlig norsk, og i data fra familiens Messenger-gruppe, ser barna ut til å respektere dette, de skriver tilnærmet standard bokmål til hverandre. Selv om det meste av tekstmeldingene i familiechatten er på norsk, er navnet de har laget på gruppa engelsk (Weee are famiiily), og familiemedlemmene har brukt gruppa til å dele bilder og filmer fra sommerferien i Senegal, der språk som wolof og arabisk brukes. Familie-chatten illustrerer slik det norske språkets sentrale posisjon i familien Coly, men også deres flerspråklige familieidentitet. Med den utstrakte bruken av norsk i familien, får det desto større effekt når datteren ved enkelte anledninger velger å bruke både fransk og arabisk i SMS-utveksling med moren, og moren viste fornøyd fram eksempler på dette. Familiens 
bånd bygges slik også digitalt, hovedsakelig på norsk, men rundt en flerspråklig familieidentitet.

Identitetsuttrykk i én-til-én-kommunikasjon skiller seg fra det å framvise identitet på sosiale medier, der en må fungere som «kurator» for narrativen om seg selv. Gjennom utvelgelse av hva en skal publisere eller ei, formidles et bilde av hvem en er (Darvin, 2016: 531), brukeren utfører context design når de stiliserer postene sine for et komplekst og mindre oversiktlig publikum enn i private samtaler (Tagg \& Seargeant, 2019: 3). Far i Diagne-familien har både norske og senegalesiske kontakter på Facebook og forteller i tråd med tanken om context design at han tenker seg om i forhold til dette før han legger ut noe. Da datteren lagde bursdagskake til han, med «gratulerer [farens navn] pappa klem» skrevet på med glasur, tok han bilde av den og la den ut på profilen sin med kommentaren «merci [datterens navn]».

\section{[Interaksjonsdata (Facebook), eksempel 6]}

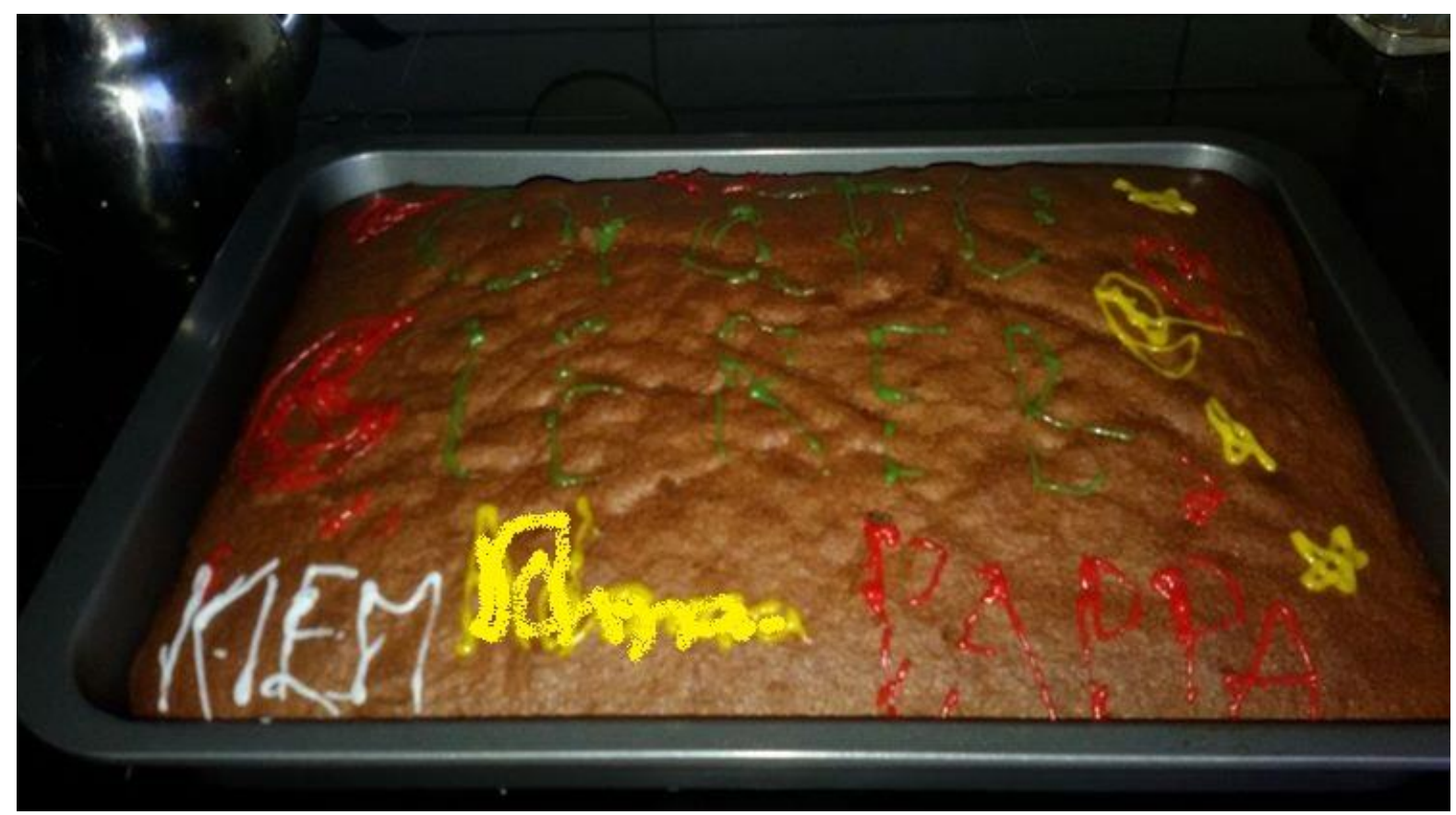

Faren forteller at han valgte «merci» fordi både norske og senegalesiske venner ville forstå. Uten denne teksten ville det være vanskeligere for ikke-norsktalende venner å skjønne betydningen av bildet. Han nådde begge grupper. Kommentarene til posten, i første rekke bursdagshilsener, kom på norsk, fransk og engelsk, og far Diagne takket for hilsenene på samme språk. Han viser seg slik som en flerspråklig person som varierer språkbruk i takt med sine samtalepartnerne. Gjennom bildet av kaken der datteren har skrevet på norsk for så å takke henne på fransk, framstiller han også familien som flerspråklig. På samme måte som familien Coly gjennom sin hushold-interne kommunikasjon skaper en flerspråklig norsktalende familieidentitet, framstiller far Diagne sin familie som norsktalende og flerspråklig på Facebook. 


\section{$6 \quad$ Konklusjon}

Denne artikkelen viser at digital kommunikasjon er en læringsarena for norsk språk som deltakerne benytter for å utvikle sine egne og familiemedlemmers språkkunnskaper. Den supplerer skolegang og annen språklæring gjennom interaksjon, og framstår som et trygg arena, der normativitet følges av en aksept for diversitet. De lærer å skrive, de øver seg på staving, de samtaler og uttrykker intimitet på norsk. Slik blir bruk av norsk og utforskning av det norske språket en familieaktivitet der det bygges en felles identitet.

Bruken av skriftlig og muntlig norsk inkluderer både bokmål, dialekt og multietnolektisk stil, knyttet til familiemedlemmenes alder og kommunikasjonssituasjonen. I et livsløpsperspektiv ser vi også at bruken av norsk i tekstmeldinger henger sammen med at foreldrene i familiene i liten grad har skrevet wolof, selv om dette språket nå er utbredt i ulike former for skriftlig uformell digital kommunikasjon i Senegal (Lexander, 2011). Fokuset på norskkunnskaper i familiene gjenspeiler også den dominerende diskursen i norsk politikk og i norske medier: norsk språk er billetten til økonomisk, sosial og kulturell kapital i Norge (Kulbrandstad, 2017).

Bruken av norsk alene som digitalt samhandlingsspråk oppfattes likevel ikke som helt uproblematisk, da både foreldre og barn også ønsker å utvikle kompetanse i språk knyttet til Senegal, og de ser at det er få rom for dette. Mange opplever imidlertid at barnas digitale kommunikasjon med slekt og venner i hjemlandet er et slikt rom, der de får brukt og utviklet sin flerspråklighet. Noe flerspråklig språkbruk finner vi også i de fire familienes skriftlige digitale samhandling. Ekteparet Diagne bruker fransk for å uttrykke følelser overfor hverandre, og mor og datter i Coly-familien bruker både fransk, arabisk og engelsk i samtaler der selve flerspråkligheten uttrykker nærhet. Far og datter Sagna sveiper innom engelsk i sin daglige kommunikasjon, og på Facebook framvises flerspråklige identiteter. Flere språk brukes for å konstruere familiens identitet innad og utad, som både norsk og knyttet til Senegal.

Når svært lite forskning på flerspråklige familier har studert digitalt mediert interaksjon, er et viktig område blitt neglisjert. I andrespråksforskningen må vi se ikke bare på undervisningskonteksten bedyrer Douglas Fir Group (2016), vi må også studere aktørskap og aktivitet på grasrotnivå, på tvers av private og offentlige, digitale og ikke-digitale kontekster. Denne artikkelen viser at også andrespråksforskningen bør ta inn familiens digitale kommunikasjon når en skal forstå hvordan og hvorfor innlærere investerer i språk.

\section{Referanser}

Androutsopoulos, J. \& A. Georgakopoulou. (2003). Discourse constructions of youth identities: Introduction. I J. Androutsopoulos \& A. Georgakopoulou. (red.), Discourse constructions of youth identities (s. 1-25). Amsterdam, Philadelphia: John Benjamins. 
Benson, P. (2015). Commenting to learn: Evidence of language and intercultural learning in comments on YouTube videos. Language Learning and Technology 19 (3), 88-105. http://dx.doi.org/10125/44435

Bourdieu, P. (1982) Ce que parler veut dire : l'économie des échanges linguistiques. Paris: Fayard.

Busch, B. (2012). Linguistic repertoire revisited. Applied Linguistics 33 (5), 503-523. https://doi.org/10.1093/applin/ams056

Curdt-Christiansen, X.-L. (2009). Invisible and visible language planning: Ideological factors in the family language policy of Chinese immigrant families in Quebec. Language Policy 8(4), 351-375. https://doi-org.ezproxy.uio.no/10.1007/s10993-009-9146-7

Da Costa Cabral, I. (2018). From Dili to Dungannon: An ethnographic study of two multilingual migrant families from Timor-Leste. International Journal of Multilingualism 15(3), 276-290. https://doi-org.ezproxy.uio.no/10.1080/14790718.2018.1477289

Darvin, R. (2016). Language and identity in the digital age. I S. Preece. (red.), Routledge Handbook of language and identity (s. 523-540). London: Routledge.

Darvin, R. \& B. Norton. (2016). Identity and a model of investment in applied linguistics. Annual Review of Applied Linguistics 35, 36-56.

https://doi.org/10.1017/s0267190514000191

Douglas Fir Group. (2016). A transdisciplinary framework for SLA in a multilingual world. The Modern Language Journal 100, 19-47. https://doi.org/10.1111/modl.12301

Fogle, L. W. \& K. King. (2017). Bi- and multilingual family language socialization. I P. A. Duff \& S. May. (red.), Language Socialization. Encyclopedia of Language and Education (s. 79-95). New York: Springer.

Gee, J., \& Hayes, E. (2011). Language and learning in the digital age. London: Routledge. Johanson, L.B. \& Karlsen, S.S. (2018). Restart: å være digital i skole og utdanning, Oslo: Universitetsforlaget.

Jølbo, I. (2014). Identitetskonstruksjoner i andrespråkstekster til elever med somalisk språkbakgrunn. Nordand 9 (2), 73-97.

Golden, A. \& G. B. Steien. (2018). "Snakke med ved? Snakke med maskin?" Voksne flyktningers narrativer om norskopplæring. Acta Didacta 12(3), 1-24. https://doi.org/10.5617/adno.5916

Hårstad, S., \& T. Opsahl. (2013). Multietnolektisk stil: Utviklingstendenser i flerspråklige miljøer. I S. Hårstad \& T. Opsahl. (red.), Språk i byen: Utviklingslinjer i urbane språkmiljøer i Norge (s. 107-144). Bergen: Fagbokforlaget. 
Kenner, C., M. Ruby, J. Jessel, E. E. Gregory \& T. Arju. (2008). Intergenerational learning events around the computer: A site for linguistic and cultural exchange. Language and Education 22(4), 298-319. https://doi.org/10.2167/le774.0

Kheirkhah, M. \& A. Cekaite. (2017). Siblings as language socialization agents in bilingual families. International Multilingual Research.

https://doi.org/10.1080/19313152.2016.1273738

King, K. A. (2013). A tale of three sisters: Language ideologies, identities, and negotiations in a bilingual, transnational family. International Multilingual Research Journal 7 (1), 49-65. https://doi.org/10.1080/19313152.2013.746800

King, K. \& E. Lanza. (2019). Ideology, agency and imagination in multilingual families: An introduction. International Journal of Bilingualism 23(3), 717-723.

https://doi.org/10.1177/1367006916684907

Kulbrandstad, L. I. (2017). Integration and language education in Norwegian policy documents 1980-2016. Apples - Journal of Applied Language Studies 11 (3), 101-120. https://doi.org/10.1111/glob.12072

Lanza, E. \& K. V. Lexander. (2019). Family Language Practices in Multilingual Transcultural Families. I S. Montanari \& S. Quay. (red.), Transdisciplinary Perspectives on Multilingualism (s. 229-251). Berlin \& New York: De Gruyter.

Lexander, K. V. (2011). Texting and African language literacy. New Media \& Society 13(3), 427-443. https://doi.org/10.1177/1461444810393905

Lexander, K.V. (2018). Nuancing the Jaxase - young and urban texting in Senegal. I C. Cutler \& U. Røyneland. (red.), Multilingual Youth Practices in Computer Mediated Communication (s. 68-86). Cambridge: Cambridge University Press.

Lexander, K. V. \& J. Androutsopoulos. (2019). Working with mediagrams: A methodology for collaborative research on mediational repertoires in multilingual families. Journal of Multilingual and Multicultural Development, publisert på nett. https://doi.org/10.1080/01434632.2019.1667363

Madianou, M. (2014). Polymedia Communication and Mediatized Migration: An Ethnographic Approach. I K. Lundby. (red.), Mediatization of Communication (s. 323-348). Berlin: De Gruyter.

Norton, B. (2013). Identity and language learning: Extending the conversation (2. utgave). Bristol: Multilingual Matters.

Norton, B. (2016). Identity and language learning: Back to the future. TESOL Quarterly 50 (2), 475-479. https://doi.org/10.1002/tesq.293 
Obojska, M. \& J. Purkarthofer. (2018). 'And all of a sudden, it became my rescue': Language and agency in transnational families in Norway. International Journal of Multilingualism 15(3), 249-261. https://doi.org/10.1080/14790718.2018.1477103

Opsahl, T. \& F. Aarsæther. (2015). Interaksjonelle tilnærminger i andrespråksforskninga. NOA norsk som andrespråk 30 (1-2), 121-150.

Parven, A. (2016). A young child's intergenerational practices through the use of visual screen-based multimodal communication to acquire Qur'anic literacy. Language and Education 30(6), 500-518. https://doi.org/10.1080/09500782.2016.1141935

Pavlenko, A. \& A. Blackledge. (2004). Introduction: New theoretical approaches to the study of negotiation of identities in multilingual contexts. I A. Pavlenko \& A. Blackledge. (red.), Negotiation of Identities in Multilingual Contexts (ss. 1-33). Clevedon: Multilingual Matters.

Purkarthofer, J. (2019). Building expectations: Imagining family language policy and heteroglossic social spaces. International Journal of Bilingualism 23(3), 724-739.

https://doi.org/10.1177/1367006916684921

Purkarthofer, J. \& G. B. Steien. (2019). «Prétendre comme si on ne connaît pas une autre langue que le swahili»: Multilingual parents in Norway on change and continuity in their family language policies. International Journal of the Sociology of Language 255, 109-131. https://doi.org/10.1515/ijsl-2018-2005

Rampton, B. (1995). Crossing: Language and ethnicity among adolescents. London: Longman.

Rotevatn, A. G. (2014). Språk i spagaten. Facebook-språket. Om normert språk og dialekt blant vestlandselevar. Masteroppgave Høgskulen i Volda.

Røyneland, U. (2018). Virtually Norwegian: Negotiating language and identity on YouTube. I C. Cutler \& U. Røyneland. (red.), Multilingual Youth Practices in Computer Mediated Communication (s. 145-168). Cambridge: Cambridge University Press.

Røyneland, U. \& B. Uri. (2020). Dialect Acquisition and Migration in Norway - Questions of Authenticity, Belonging and Legitimacy. Journal of Multilingual and Multicultural Development, publisert på nett.

Said, F. \& Hua, Zhu. (2018). No, no Maama! say "shaatir ya ouledee shaatir"!" : Children's agency and creativity in language use and socialisation. International Journal of Bilingualism, 23 (3), 771-785. https://doi-org.ezproxy.uio.no/10.1177/1367006916684919

Skog, B. (2009) Språket på Facebook. Språknytt 37(1), 23-25.

Statistisk Sentralbyrå. (2019). Innvandrere og norskfødte med innvandrerforeldre. https://www.ssb.no/befolkning/statistikker/innvbef. 
Strand, T. (2019). Tradition as innovation: Dialect revalorization and maximal orthographic distinction in rural Norwegian writing. Multilingua 38(1), 51-68.

https://doi-org.ezproxy.uio.no/10.1515/multi-2018-0006

Stæhr, A. (2015). Reflexivity in Facebook interaction - Enregisterment across written and spoken language practices. Discourse, Context \& Media 8, 30-45.

https://doi.org/10.1016/j.dcm.2015.05.004

Szecsi, T. \& J. Szilagyi. (2012). Immigrant Hungarian families' perceptions of new media technologies in the transmission of heritage language and culture. Language, Culture and Curriculum 25(3), 265-281. https://doi.org/10.1080/07908318.2012.722105

Tagg, C. \& P. Seargeant. (2019). Context design and critical language/media awareness: Implications for a social digital literacies education. Linguistics and Education, online first. https://doi.org/10.1016/j.linged.2019.100776

Tannenbaum, M. \& Yitzhaki, D. (2016). 'Everything comes with a price ... '; family language policy in Israeli Arab families in mixed cities. Language and Intercultural Communication 16(4), 570-587. https://doi-org.ezproxy.uio.no/10.1080/14708477.2016.1195395

Wedin, Å. (2017). Arbete med identitetstexter. Flerspråkit skrivande för identitetsförhandling och engagemang. Nordand 1, 45-61.

https://doi.org/10.18261/issn.2535-3381-2017-01-04

Weidl, M. (2019). The role of Wolof in multilingual conversations in the Casamance: Fluidity of linguistic repertoires. London: SOAS University of London upublisert PhD-avhandling.

\footnotetext{
' "the way a person understands his or her relationship to the world, how that relationship is structured across time and space, and how the person understands possibilities for the future»

Takk til Hanna Solberg Andresen, Jannis Androutsopoulos, Anne Golden, Toril Opsahl, redaksjonen og to anonyme fagfeller for tilbakemeldinger på tidligere utkast. Takk til Natacha Céline Buntinx og Marit Johanne Furunes for hjelp med det grafiske. Tusen takk til de fire familiene som har deltatt $i$ studien.
}

Dette arbeidet er finansiert av Norges forskningsråd gjennom ordningen Sentre for fremragende forskning, prosjekt nummer 223265.

\section{Norwegian as language of digital interaction in four migrant background families - identity and investment}

This paper contributes to the research on Norwegian as a second language through an analysis of its role in digital interaction in the family context. Second language learners' ideas of language needs and wishes change with the use of new information and communication technology (Darvin \& Norton 2015; Douglas Fir Group, 2016). Through digital interaction, 
migrants may stay closer in touch with family and friends in the country of origin, and they can also build networks in the country of residence and develop their language competence. How does this influence on the use of Norwegian in migrant families in Norway? In the analysis of interview data, interactional and observational data, the following questions are discussed: How is digital communication used to develop Norwegian language competence in the family? What are the relations between the family members' perspectives on identity and their use of Norwegian? The aim is to understand what digital use of Norwegian can tell us about Norwegian as a second language in family communication.

Keywords: Digital interaction, family language practices, informal language learning 